UDC 577.1

\title{
Modification of the Spike Protein for Vaccines against Enveloped RNA Viruses
}

\author{
A. N. Vzorov ${ }^{a, b}, *$, E. I. Samokhvalov ${ }^{a}$, V. V. Chebanenko ${ }^{b}$, \\ D. V. Scheblyakov ${ }^{a}$, and A. L. Gintsburg ${ }^{a, c}$ \\ ${ }^{a}$ Gamaleya National Research Center of Epidemiology and Microbiology, \\ Ministry of Healthcare of the Russian Federation, Moscow, 123098 Russia \\ ${ }^{b}$ Biological Faculty, Moscow State University, Moscow, 119234 Russia \\ ${ }^{c}$ Department of Infectiology and Virology, Sechenov First Moscow State Medical University, \\ Ministry of Health of the Russian Federation, Moscow, 123098 Russia \\ *e-mail:anvzorov@mail.ru \\ Received March 4, 2021; revised March 22, 2021; accepted March 22, 2021
}

\begin{abstract}
Most vaccines work by inducing neutralizing antibodies that target the viral envelope. Enveloped RNA viruses have evolved mechanisms for surface glycoproteins to evade host immune responses, which exhibit substantial variability, even among different strains. Natural infection and vaccines using native forms of surface proteins may induce broadly neutralizing antibodies, yet with low and ineffective levels. Class I membrane-fusion proteins of enveloped RNA viruses, HIV-1, influenza A virus, SARS-CoV-2, yield a stable conformation (so-called "pre-fusion") in providing fusion between viral and host cell membranes. Modified viral surface proteins that are based on these features induce neutralizing antibodies with activity available against a broad spectrum of circulating strains and make it possible to overcome the difficulties associated with escape/variability of viral antigen.
\end{abstract}

Keywords: enveloped RNA viruses, SARS-CoV-2, HIV-1, influenza A virus, spike protein, haemagglutinin, Env, fusion mechanisms, neutralizing antibodies, vaccines

DOI: $10.1134 / \mathrm{S} 0026893321030158$

In the twentieth century, most vaccines were designed using traditional techniques which involve pathogen isolation, pathogen inactivation, and immunization, or using viral proteins in their natural forms [1]. However, new approaches should be used to "defeat" new pathogens, mainly because of the high variability in their genomes and the conformational flexibility of their surface glycoproteins. It should be noted that vaccines containing whole inactivated virions are less safe than subunit vaccines containing individual viral components.

\section{SPREAD OF ENVELOPED RNA VIRUSES}

Most human RNA viruses are thought to be zoonotic or of zoonotic origin [2]. HIV-1, influenza A virus, and SARS-CoV-2 are enveloped viruses with RNA genomes. Owing to their high variability, these viruses were able to cross the species barrier, enter the human population, and become adapted to humans (Table 1). The epidemic spread of new viruses is most likely due to increasing population density, growing urbanization, the development of transportation, the behavior of viruses themselves, and their adaptation to humans. The global community is now in one of the most dramatic health crises of the past decade. The emergence of the new RNA-containing enveloped SARS-CoV-2 virus, the etiological agent of COVID-19, became one of the key causes of increased mortality worldwide. The SARS-CoV-2 genome is similar to both SARS-CoV (79\%) and MERS-CoV (50\%), but is most closely related to the two SARS-like bat viruses bat-SL-CoVZC45 and bat-SL-CoVZXC21 (88\% similarity) [3]. The new SARS-CoV-2 virus was officially categorized into the Sarbecovirus subgenus of the Betacoronavirus genus.

\section{STRUCTURAL CHANGES OF VIRAL ENVELOPE GLYCOPROTEINS DURING ENTRY INTO CELLS}

Envelope proteins, which have similar structural patterns in RNA viruses such as influenza A virus, SARS-CoV-2, and simian immunodeficiency virus/HIV, are the key target of the adaptive immune response. The trimeric transmembrane proteins of these viruses are Class I fusion proteins with a single transmembrane domain [15]. As part of the viral envelope, glycoproteins S (SARS-CoV), Env (HIV/SIV), and HA (influenza virus) participate in two key events: cell 
Table 1. Adaptation of the zoonotic enveloped RNA viruses, HIV, influenza A virus, and SARS-CoV-2 to the human host

\begin{tabular}{l|l}
\hline Factors affecting spread of viruses in the human population & \multicolumn{1}{|c}{ The role of the surface glycoprotein (spike) } \\
\hline Seasonal potential for airborne transmission [4] & $\begin{array}{l}\text { Responsible for cell entry. } \\
\text { Recognizes cell receptors }\end{array}$ \\
\hline Adaptation to human cells [5] & $\begin{array}{l}\text { Cell tropism alteration mechanism and modulation of virus } \\
\text { receptor specificity [6] }\end{array}$ \\
\hline Asymptomatic transmission & Accumulation of adaptive mutations [7-9] \\
\hline $\begin{array}{l}\text { Innate immunity [10]; preexisting immunity: cross-reactive } \\
\text { antibodies and cross-reactive T-cell immunity [11, 12] }\end{array}$ & Ability to counteract antiviral immunity [13] \\
\hline $\begin{array}{l}\text { Adaptive immunity; } \\
\text { antiviral drugs }\end{array}$ & $\begin{array}{l}\text { Ability to evade the immune response and antiviral therapy; } \\
\text { genetic variability and conformational flexibility [14] }\end{array}$ \\
\hline
\end{tabular}

receptor binding, and induction of fusion of the viral and cell membranes (Table 1 and Fig. 1). Virus particles can enter the cell without binding a specific receptorvia endocytosis. However, this entry route does not result in a productive infection [16]. The fulfilment of the two conditions, the recognition of cell surface receptors as well as viral and cellular membrane fusion, results in viral entry into the cell, and triggering the virus' replication cycle. Upon membrane fusion, viral surface glycoproteins go through a cascade of strictly regulated conformational changes resulting in stabilized protein forms.

Envelope proteins are synthesized as precursors, which are further processed to the surface and membrane-anchored subunits. The newly formed N-terminus contains the hydrophobic fusion peptide. Most Class I fusion proteins contain the receptor-binding domain (RBD), which clamps the fusion-inducing domain ${ }^{1}$. Protein refolding and stabilization are triggered only after virus-receptor binding when the target membrane is within reach. It is thought that it is the stabilized forms which exhibit conservative surfaces and bear the epitopes which are recognized by neutralizing antibodies with high cross-reactivity, while metastable forms have these epitopes hidden inside and expose the most variable regions which induce the production of non-neutralizing antibodies $[20,21]$.

\section{IMMUNOGENICITY OF VIRAL ENVELOPE PROTEINS}

HIV-1 envelope glycoprotein. HIV-1 is a complex retrovirus which encodes several accessory proteins in addition to the structural proteins (Gag, Pol, and Env)

\footnotetext{
${ }^{1}$ The triggers of membrane fusion (low $\mathrm{pH}$ or receptor binding) loosen the association between the surface and the transmembrane (TM) domains (subunits) of the spike protein thus allowing TM to get free from the clamp (certain protein fragments shield/clamp other fragments in a metastable protein form) and undergo refolding. The $\alpha$-helical TM region changes its conformation and pushes another TM region, the hydrophobic fusion peptide, towards the cellular membrane.
}

present in all retroviruses. Humans possess protective immunity against simple retroviruses [22], while natural HIV infection does not induce the protective immune response. The accessory HIV-1 proteins inhibit cellular antiviral restriction factors. In addition, HIV has developed many other mechanisms that allow it to evade and even counteract the host's protective response. One such viral factor is associated with the surface glycoprotein Env. The level of neutralizing antibodies against the Env protein produced during natural infection is insufficient to block the infection [23]. Immunogens based on native Env trimers induce a strong, although strain-specific, neutralizing antibody responses in animal models. However, immunogens based on native Env trimers are unable to create the conditions for overcoming the many obstacles on the way to the production of broadly neutralizing antibodies $[24,25]$. A vaccine targeted to inhibit HIV entry into the cell will be efficient only if it induces the production of potent broadly neutralizing Env-specific antibodies.

Influenza A virus haemagglutinin. Haemagglutinin (HA) is the most commonly used component of antiinfluenza vaccines. There exist 18 different antigenic subtypes of influenza A virus HA [26]. There are two main mechanisms which allow the influenza A virus to evade the immune response and spread in the human population, antigenic drift and antigenic shift. Antigenic drift is the result of mutations in the genes encoding the surface glycoproteins HA and neuraminidase (NA) which arise in response to the selective pressure produced by host antibodies. Antigenic shift is the emergence of new influenza A virus strains as a result of reassortment of genomic segments from different strains [27]. Current certified anti-influenza vaccines contain either inactivated, or live attenuated influenza viruses. The efficiency of protection exerted by seasonal certified vaccines changes each year depending on the antigenic correspondence between the circulating viruses and the vaccine strains and varies from 20 to $60 \%[28,29]$. Although influenza vaccines are effective against closely related viruses, their main limitations include the need to update the pro- 
(a)

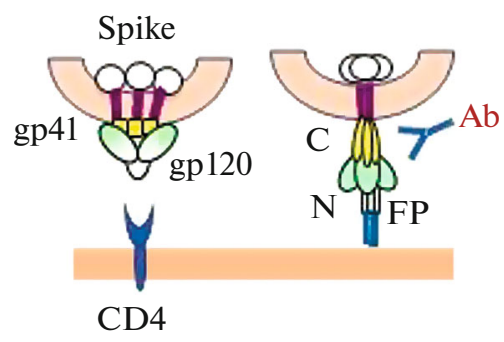

(b)

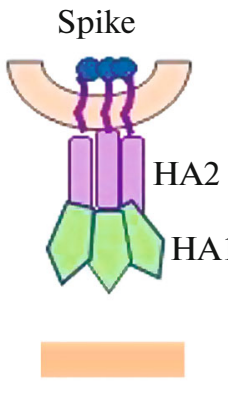

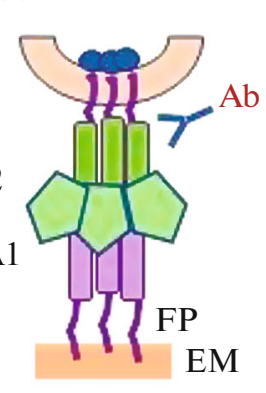

(c)

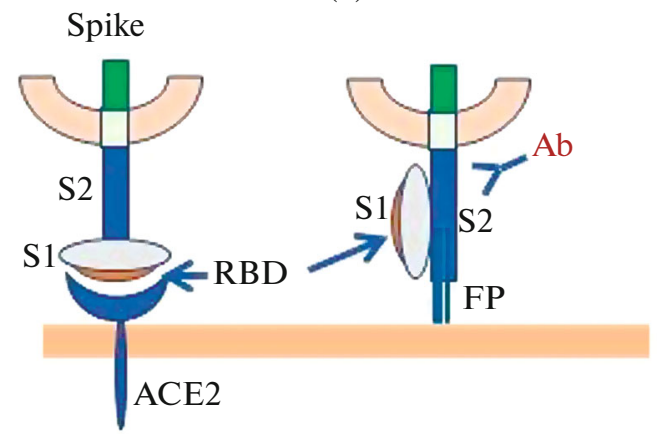

Fig. 1. The structure of spike proteins of enveloped viruses. The spike protein exists in a metastable state on the surface of the virion: HIV (a), influenza A virus (b), and SARS-CoV-2 (c). Receptor binding (a and c), or a change in pH (b) leads to a change in protein conformation including surface subunit refolding and transmembrane subunit stabilization which results in the prefusion spike form. Additional epitopes inducing neutralizing antibody formation become exposed in the pre-fusion protein conformation [17-19]. The pre-fusion spike protein form may be stabilized by introducing modifications, for example, a trimerizing sequence, or by site-directed mutagenesis. FP-fusion peptide, EM-endosome membrane, RBD-receptor-binding domain, and $\mathrm{Ab}$-antibody.

duction for each epidemic season, with an uncertainty about the accuracy of the choice of current seasonal strains. When pandemic strains, which have successfully crossed the primary host-human interspecific barrier, enter the human population, vaccine development and production should be started from almost the very beginning due to the high probability of change in the influenza virus subtype.

SARS-CoV-2 spike protein. Coronaviruses possess genetic proofreading mechanisms [30,31]. For this reason, the genetic divergence of SARS-CoV-2 is low compared to other RNA viruses (e.g. HIV) [32]. However, natural selection may facilitate the appearance of rare mutations favorable for the virus. Recent phylogenetic studies have demonstrated that the rate of evolution of the virus genome is accelerated in patients who suffer from long lasting infection and receive antiviral therapy, with amino acid changes occurring predominantly in the spike protein, mostly in RBD [14]. There is a study which reported protracted COVID-19 in a patient with lymphoma, which was confirmed by positive RT-PCR results for over four months. During this period the virus got 18 de novo mutations [33]. Many studies have demonstrated that the SARS-CoV-2 variant containing the D614G mutation in the spike protein rapidly became prevalent in the human population during the 2020 pandemic [34, 35]. Now, a new SARS-CoV-2 variant B.1.1.7 caused a sharp increase in the number of disease cases, first in England, and then worldwide. The B.1.1.7 genome is characterized by an unusually large number of substitutions which result in many mutations in the spike protein, three of which are the most alarming. The N501Y mutation involving one of the six key amino acid residues in RBD was identified as increasing the affinity of spike protein binding with the human and mouse SARS-CoV-2 receptor, angiotensin-converting enzyme-2 (ACE2). The 69-70 del deletion in the $\mathrm{S}$ protein may have an effect on immune response evasion. The $\mathrm{P} 681 \mathrm{H}$ mutation is in immediate proximity to the furin cleavage site, an important determinant of the virus infectious cycle [36]. Another SARS-CoV-2 variant, B.1.351, was detected in South Africa. Although B.1.351 shares some mutations with B.1.1.7 it is considered to have emerged independently from the British strain. The SARS-CoV-2 variant known as P.1 emerged in Brazil. This variant contains 17 unique mutations including 3 mutations in the RBD of the spike protein [37]. A new B.1.525 variant containing two significant mutations E484K and F888L which increase transmission and virulence of SARS-CoV-2 and attenuate the neutralizing antibody activity was registered simultaneously in Great Britain and Nigeria [38]. The analysis of the current epidemiological situation has raised the concern that even if heard immunity is obtained, SARS-CoV-2 will continue to circulate in the human population and previous infection will not protect against reinfection [39] (Table 2). For example, virus genomes isolated from a patient who had COVID-19 twice belonged to different SARS-CoV-2 strains [39]. It was reported [40] that non-neutralizing antibodies predominate in patients that have recovered from COVID-19, while the quantities of neutralizing antibodies against the SARS-CoV-2 spike protein are low (Table. 2 ).

Antibodies targeted against the receptor-binding motif (RBM) of the RBD of the S protein predominate in the humoral immune response in patients who have recovered from COVID-19 [43]. Immunodominant RBM epitopes induce the production of antibodies which block $\mathrm{S}$ protein binding with the receptor. However, mutations in the immunodominant epitope occur much more frequently than in the non-immunodominant epitope. As a result a mutant SARS-CoV-2 may easily evade neutralizing antibodies. It has already been demonstrated that the antibody responses induced by the natural SARS-CoV-2 infection involve a wide 
Table 2. The comparison of the antibody response (Abs) directed against the envelope protein in HIV-1 and SARS-CoV-2 patients

\begin{tabular}{l|l|l}
\hline \multirow{2}{*}{ Antibodies } & \multicolumn{2}{c}{ Efficiency/level } \\
\cline { 2 - 3 } & \multicolumn{1}{c}{ HIV-1 } & \multicolumn{1}{c}{ SARS-CoV-2 } \\
\hline Polyclonal (in blood) & No protection from reinfection & No protection from reinfection \\
\hline Monoclonal (isolated from patients) & $\begin{array}{l}\text { Neutralizing antibodies acting according } \\
\text { to the effector mechanism [41] }\end{array}$ & $\begin{array}{l}\text { Neutralizing antibodies acting accord- } \\
\text { ing to the effector mechanism [42] }\end{array}$ \\
\hline Neutralizing & Low level & Low level \\
\hline Non-neutralizing & High level & High level \\
\hline
\end{tabular}

range of S-protein epitopes (neutralizing and nonneutralizing). This phenomenon is also a notable feature of the HIV-1 surface Env protein in chronic infection when this protein exists in a relaxed conformation. In the case of the primary infection, Env exists in a compact form and mostly induces a targeted immune response directed against the neutralizing epitopes. Given this compact form, the Env can be used as a platform that produces immunogens for antiHIV vaccines [20]. Interestingly, the affinity of monoclonal antibody binding with the RBD of the coronavirus $S$ protein isolated from patients that recovered from COVID-19 did not correlate with neutralizing ability [44]. For example, the monoclonal 2M-10B11 antibody bound the RBD $\left(\mathrm{EC}_{50} 5 \mathrm{ng} / \mathrm{mL}\right)$ but did not neutralize authentic SARS-CoV-2; while 4A8, in contrast, showed high neutralizing activity, but did not bind RBD [44]. This may be due to the specific structure and conformational transitions in the native spike protein. On the other hand, not with standing primary RBM structures being different in SARS-CoV and SARS-CoV-2 both coronaviruses show high-affinity binding with ACE2 as with their proper receptor. Hence, the pattern of interaction between RBM and ACE2 may vary between different sarbecoviruses. However, the mechanisms of this interaction are still unclear.

The continuing pandemic may also facilitate the accumulation of immunologically relevant mutations in the SARS-CoV-2 genome as a result of the use of vaccines. However, it should be noted that natural SARS-CoV-2 infection may cause the production of neutralizing antibodies with a broad spectrum activity. The S309 antibodies isolated from a patient with SARS-CoV interacted with the RBD of the S glycoprotein and efficiently neutralized both SARS-CoV and SARS-CoV-2 [45]. Using cryo-electron microscopy and binding analysis S309 antibodies were found to recognize an epitope which is conserved in the Sarbecovirus subgenus and not compete for RBM binding with the receptor. The epitope can be reached in both the open and the closed $\mathrm{S}$ glycoprotein conformation [45]. It was suggested that one, or several IgG-specific bivalent mechanisms are employed in neutralization, namely, S protein trimer cross-linking (between the trimers within a single virion), creating steric constraints, or virion aggregation (as a result of virion cross-linking).

Using a primate model Yu et al. [45] demonstrated that neutralizing antibody titers induced by the antiSARS-CoV-2 vaccine correlate with the vaccine's protective activity.

\section{APPROACHES TO THE MODIFICATION OF ENVELOPE PROTEINS}

To enhance the antibody response is the main goal when creating an immunogen for the antiviral vaccine. An effective immunogen may be constructed using a mechanistic strategy based on structural identification of evasion mechanisms [46]. The use of trimeric stabilized forms of viral surface proteins is drawing increasing attention in immunogen design [15]. It has already been shown that stabilized SIV/HIV Env trimers do not induce the "immune off-target responses" and non-neutralizing antibodies. The latter are formed in response to nonnative epitopes present in the natural forms of Env in viral particles [47, 48] (Table 3). The introduction of the GCN4 trimerizing sequence, the derivative of the leucine zipper motif of the yeast regulatory protein GCN4 [49], into the Env cytoplasmic domain resulted in the formation of a bundle structure stabilizing the surface subunit and exerted a significant effect on the functional activity of HIV and SIV Env proteins including modulation of the receptor-binding site exposure [50, 51]. Moreover, stabilized SIV/HIV trimers induce the production of broadly neutralizing antibodies with increased avidity, which allows them to be considered as potential immunogens for vaccines with enhanced efficiency [52].

Regarding the influenza A virus, Weldon et al. (2010) showed that native epitopes are exposed on the soluble form of the recombinant HA trimer (sHA) containing the GCN4 trimerizing sequence at the $\mathrm{C}$-terminus, whereas unmodified sHA protein exposes the epitopes that are not exposed on the native molecule [53]. The epitopes present in the unmodified sHA are located on the "silent face" of the trimer, that is, on the monomer-monomer interface, and for this reason the antibody response is distorted. These epitopes are 
Table 3. Differences between the natural and stabilized forms of the HIV/SIV, influenza A virus, and SARS-CoV-2 envelope proteins

\begin{tabular}{|c|c|}
\hline Natural protein & Stabilized form \\
\hline Metastable conformation & The pre-fusion conformation \\
\hline Immune system "disorientation" & Do not cause immune system "disorientation" \\
\hline Non-native epitope exposure & Exposure of the native trimer epitopes \\
\hline Induction of non-neutralizing antibodies & Induction of broad-spectrum antibodies with high avidity \\
\hline
\end{tabular}

not exposed on the virion at physiological $\mathrm{pH}$. The stabilized sHA trimer proved to be a more efficient immunogen than the unstabilized initial form and thus can be taken advantage of when developing anti-influenza vaccines. These data once again show that it is important to design an immunogen based on the structural modifications of the viral antigen.

The currently available data on the mechanism of SARS-CoV-2 entry into the host cell and antibodymediated neutralization of this virus [42, 54, 55] allow structural design of immunogens for vaccines against highly pathogenic coronaviruses, including those which may appear in the future. For example, Rey and Lok (2018) reported that the insertion of the trimerization motif into the HIV and influenza A virus fusion proteins stabilizes the entire trimer [56]. In coronaviridae viruses, the trimerization motif did not exert any effects on the HR2 region (C-terminal heptad repeat 2) of the $\mathrm{S}$ protein, which existed in a disordered conformation and didn't participate in trimer stabilization. To address this issue, Pallesen et al. (2017) introduced two proline residues (S-2P) into the HR1 of MERS-CoV, which allowed for a 50-fold increase in immunogen production in human epithelial cells compared to the native protein, the level of neutralizing antibodies induced by this protein in immunized animals was significantly higher than that obtained in the case of the unmodified molecule [57]. It has been recently demonstrated that SARS-CoV-2 S protein stabilized by the introduction of the two proline residues became conformationally homogeneous and existed in the pre-fusion conformation which displays neutralization-sensitive epitopes [55], this is importance when using $\mathrm{S}$ protein as an immunogen. Additional epitopes inducing the production of neutralizing antibodies become exposed in the pre-fusion conformation. A high-resolution 3D structure of the MERS-CoV S protein-G4 neutralizing antibody complex was analyzed which revealed that these antibodies are targeted against the stem region (the outer part of the fusion protein molecule) [57]. Additionally, G4-antibodies targeted against the stabilized MERSCoV S protein form were obtained in mice. These antibodies binding with the $\mathrm{S} 2$ subunit are targeted against the epitopes located outside the RBD and are able to efficiently neutralize the virus [19].

The modified RNA vaccine BNT162b2 encoding the full-size SARS-CoV-2 S glycoprotein stabilized in the pre-fusion conformation induced the production of broadly neutralizing antibodies in vaccinated patients [58]. To study the efficiency of the immune response induced by the $\mathrm{BNT} 162 \mathrm{~b} 2$ vaccine, the infectious complementary SARS-CoV-2 DNA (cDNA) was obtained. Based on this cDNA Xie et al. (2021) constructed three mutant viruses with spikes composed of $\mathrm{S}$ protein containing the key mutations found in the recently detected British and South African variants (B.1.1.7 and B.1.351, respectively) [58]. The analysis of the sera panels obtained from 20 participants of the BNT162b2 vaccine clinical trials demonstrated that all participants produced neutralizing antibodies against all three mutant viruses at high levels. Despite the fact that blood plasma was used from those who recovered from COVID-19, the 501Y.V2 mutant may evade the neutralizing antibodies [59].

\section{SARS-COV-2 VACCINES BASED ON S-PROTEINS}

Currently, 48 candidate vaccines against COVID-19 are undergoing clinical trials [60]. It should be noted that $\mathrm{S}$ protein either as a full-size $[61,64]$, or as a truncated form [63] is used as an immunogen in only a few of them [61-64]. A number of modifications have also been described, including the deletion of the proteolytic cleavage site $[65,66]$ and the introduction of two (or more) stabilizing mutations or trimerization domains [67]. In most cases, adenoviral vectors (AdV) or recently developed RNA vaccines are used for $S$ protein delivery and expression in cells. The published data from the preclinical studies of a number of candidate RNA vaccines make us optimistic about the future [62, 68]. However, RNA technology is a new branch of biotechnology, which means that both predicted and unpredicted setbacks may arise in largescale vaccine production. For example, Pfizer vaccine manufacturers have already faced the problem of stability in long-term storage and the need to maintain $-70^{\circ} \mathrm{C}$. Furthermore, RNA vaccines are injectable and therefore, unlikely to cause a strong immune response in the respiratory mucosa as well as the conjunctiva, the entry gates for SARS-CoV-2.

Adenoviral vectors can be produced in large quantities and they are more stable than the RNA vaccines in that they do not require storage at low temperatures. $\mathrm{AdV}$ vectors efficiently stimulate both the B and T-cell 
immune responses, but they may be partially neutralized due to pre-existing immunity against adenoviruses. Age and pre-existing immunity against the type 5 adenovirus (AdV5) in the participants of clinical trials proved to be the two factors which affected the safety and immunogenicity of the candidate vaccine [69]. Fever was associated with younger age and a lower level of immune response to the AdV5-based vaccine delivery vector Ad5. It was found that elderly people, who were more likely to have encountered AdV5 during their lifetime, had much higher levels of neutralizing antibodies against Ad5 than young people. Therefore, elderly people may be more tolerant to a vaccine based on the Ad5-vector.

In the view of the high number of AdV5 seropositive individuals worldwide, alternative vectors are used to produce vaccines against SARS-CoV-2. Among them are AdVs belonging to the rare serotypes including types $11,26,35$, and 49 [70], which may be used in the heterologous prime-boost schemes [61]. For example, the study of the sera samples obtained from participants involved in the clinical trials for the vaccine based on two recombinant AdV vectors rAd26 and rAd5 demonstrate that a pre-existing immunity against these two adenoviruses did not affect the antibody titers against the SARS-CoV-2 S protein RBD [61]. This may be connected to the high titers of adenovirus particles used in the analyzed vaccine, with $10^{11}$ per dose for each of the two recombinant viruses [61] or, the short time frame (up to 5 minutes)that it takes for AdV particles to attach themselves to the membrane and enter the cell [71].

According to the latest results of the SARS-CoV-2 vaccine trials, vaccines in which the $S$ protein was used as an immunogen $[61,64,72]$ confer up to 70 to $93 \%$ protection [73]. However, the question remains: "Which S protein form will give way to the most efficient vaccine against COVID-19, including the newly emerging SARS-CoV-2 strains?"

\section{CONCLUSIONS}

The rapid spread of viruses may be driven by their easy host-to-host transmission, predisposition to mutational shift/drift, and neutralizing antibody evasion by new immune variants of the virus. Whether antibodies neutralize the virus or intensify the infection depends on many parameters such as specificity, concentration, affinity, and isotype [74-76]. Hypothetically, SARS-CoV-2 may be considered the result of a natural antigenic shift which occurred in SARS-CoV given the genome sequences of these two viruses is $79 \%$ identical and the repertoires of proteins encoded by them also being similar [77]. There is a certain risk that new coronavirus strains emerging as a result of antigenic drift in the circulating strains will evade the immune response induced by the parental virus or the vaccine against it, just as the influenza virus evades the antibodies induced by the seasonal vaccines [78]. This phenomenon is due to the fact that seasonal vaccines can possibly induce inefficient weakly neutralizing antibodies against the new epitopes of the mutant virus [79]. The antibody response also depends on how accessible for the antibodies the epitope on the virus particle surface is. Immunodominant epitopes on the HIV surface induce the production of non-neutralizing antibodies. This is one of the host immune system evasion mechanisms utilized by HIV. The immunodominant epitopes "divert the attention" of the B-cells from the functional trimer sites, which are not easily accessible. In the influenza A virus and SARS-CoV-2, immunodominant epitopes induce the production of antibodies which block virus entry into the cell. The SARS-CoV-2 receptor-binding motif, RBM, is the central target for the neutralizing antibodies [43]. This site is vital for the virus and its accessibility to neutralizing antibodies, playing a dual role. The epitopes of $\mathrm{RBM}$ are prone to natural mutagenesis, which in the long run makes it possible for the virus to evade neutralization by antibodies. It is possible, that during longterm infections this may result in antigen drift, similar to that described for the influenza A virus. It is for this reason that modified $\mathrm{S}$ proteins with exposed conservative epitopes (non-immunodominant) should be used to develop antibody-inducing vaccines. Notwithstanding the apparent differences in the structure and transmission routes, HIV, influenza $A$ virus, and SARS-CoV-2 share a number of common properties. These viruses are characterized by a similar cell entry mechanism, and by the similar determinants of this process, which are surface glycoproteins recognizing their receptors on the surface of the host cell and inducing the fusion between the viral envelope and cell membrane. In HIV, influenza A virus, and SARS-CoV-2, the stabilization of the fusion protein and the exposure of its conservative surface is the key mechanism for protective antibody production [56]. New structural data might make it possible to both assess the functional importance of mutations in the $\mathrm{S}$ protein, which result from a genetic drift in the circulating SARS-CoV-2 strains and to match them to the known epitope regions in the stabilized S protein, which are accessible to the antibodies. This information will aid in the precise design of immunogens and accelerate the development of efficient vaccines.

\section{ACKNOWLEDGMENTS}

The authors are grateful to M.I. Bukrinsky for useful discussion during the preparation of the manuscript.

\section{FUNDING}

This review did not require any special funding. 


\section{COMPLIANCE WITH ETHICAL STANDARDS}

No experimentation involving animals or humans was carried out by any of the authors of this article.

The authors declare no conflict of interest.

\section{OPEN ACCESS}

This article is licensed under a Creative Commons Attribution 4.0 International License, which permits use, sharing, adaptation, distribution and reproduction in any medium or format, as long as you give appropriate credit to the original author(s) and the source, provide a link to the Creative Commons licence, and indicate if changes were made. The images or other third party material in this article are included in the article's Creative Commons licence, unless indicated otherwise in a credit line to the material. If material is not included in the article's Creative Commons licence and your intended use is not permitted by statutory regulation or exceeds the permitted use, you will need to obtain permission directly from the copyright holder. To view a copy of this licence, visit http://creativecommons.org/licenses/by/4.0/.

\section{REFERENCES}

1. Rappuoli R. 2004. From Pasteur to genomics: Progress and challenges in infectious diseases. Nat. Med. 10 (11), $1177-1185$. https://doi.org/10.1038/nm1129

2. Woolhouse M.E.J., Adair K., Brierley L. 2013. RNA viruses: A case study of the biology of emerging infectious diseases. Microbiol. Spectr. 1 (1). https://doi.org/10.1128/microbiolspec.OH-0001-2012

3. Lu R., Zhao X., Li J., Niu P., Yang B., Wu H., Wang W., Song H., Huang B., Zhu N., Bi Y., Ma X., Zhan F., Wang L., Hu T., et al. 2020. Genomic characterisation and epidemiology of 2019 novel coronavirus: Implications for virus origins and receptor binding. Lancet. 395, 565-574.

4. Herfst S., Bohringer M., Karo B., Lawrence P., Lewis N.S., Mina M.J., Russell C.J., Steel J., de Swart R.L., Menge C. 2017. Drivers of airborne human-to-human pathogen transmission. Curr. Opin. Virol. 22, 22-29.

5. Vzorov A.N., Weidmann A., Kozyr N.L., Khaoustov V., Yoffe B., Compans R.W. 2007. Role of the long cytoplasmic domain of the SIV Env glycoprotein in early and late stages of infection. Retrovirology. 4, 94. https://doi.org/10.1186/1742-4690-4-94

6. Vzorov A.N., Yang C., Compans R.W. 2015. An amphipathic sequence in the cytoplasmic tail of HIV-1 Env alters cell tropism and modulates viral receptor specificity. Acta Virol. 59 (3), 209-220.

7. Marx P.A., Alcabes P.G., Drucker E. 2001. Serial human passage of simian immunodeficiency virus by unsterile injections and the emergence of epidemic human immunodeficiency virus in Africa. Philos. Trans. $R$. Soc. Lond. B 356 (1410), 911-920.

8. Walls A.C., Park Y.-J., Tortorici M.A., Wall A., McGuire A.T., Veesler D. 2020. Structure, function, and antigenicity of the SARS-CoV-2 spike glycoprotein. Cell. 181, 281-292, e6.
9. Li W., Zhang C., Sui J., Kuhn J.H., Moore M.J., Luo S., Wong S.K., Huang I.C., Xu K., Vasilieva N., Murakami A., He Y., Marasco W.A., Guan Y., Choe H., Farzan M. 2005. Receptor and viral determinants of SARS-coronavirus adaptation to human ACE2. EMBO J. 24, 1634-1643.

10. Meffre E., Iwasaki A. 2020. Interferon deficiency can lead to severe COVID. Nature. 587 (7834), 374-376. https://doi.org/10.1038/d41586-020-03070-1

11. Ng K., Faulkner N., Cornish G., Rosa A., Harvey R., Hussain S., Ulferts R., Earl C., Wrobel A., Benton D., Roustan C., Bolland W., Thompson R., Agua-Doce A., Hobson P., et al. 2020. Pre-existing and de novo humoral immunity to SARS-CoV-2 in humans. Science. 370, 1339-1343.

12. Altmann D.M., Boyton R.J. 2020. SARS-CoV-2 T cell immunity: specificity, function, durability, and role in protection. Sci. Immunol. 5, eabd6160.

13. Exline C.M., Yang S.J., Haworth K.G., Rengarajan S., Lopez L.A., Droniou M.E., Seclen E., Cannon P.M. 2015. Determinants in HIV-2 Env and tetherin required for functional interaction. Retrovirology. 12, 67. https://doi.org/10.1186/s12977-015-0194-0

14. Choi B., Choudhary M.C., Regan J., Sparks J.A., Padera R.F., Qiu X., Solomon I.H., Kuo H., Boucau J., Bowman K., Adhikari U.D., Winkler M.L., Mueller A.A., Hsu T., Desjardins M., et al. 2020. Persistence and evolution of SARS-CoV-2 in an immunocompromised host. N. Engl. J. Med. 383, 2291-2293.

15. Waning D.L., Russell C.J., Jardetzky T.S., Lamb R.A. 2004. Activation of a paramyxovirus fusion protein is modulated by inside-out signaling from the cytoplasmic tail. Proc. Natl. Acad. Sci. U. S. A. 101 (25), 92179222.

16. Bosch B., Grigorov B., Senserrich J., Clotet B., Darlix J., Muriaux D., Este J.A. 2008. A clathrin-dynamin-dependent endocytic pathway for the uptake of HIV-1 by direct T cell-T cell transmission. Antiviral Res. 80 (2), 185-193.

17. Huang J., Kang B.H., Pancera M., Lee J.H., Tong T., Feng Y., Imamichi H., Geogiev I.S., Chuang G., Druz A., Doria-Rose N.A., Laub L., Sliepen K., van Gils M.J., de la Pena A.T., et al. 2014. Broad and potent HIV-1 neutralization by a human antibody that binds the gp41-gp120 interface. Nature. 515, 138-142.

18. Neerukonda S.N., Vassell R., Weiss C.D. 2020. Neutralizing antibodies targeting the conserved stem region of influenza hemagglutinin. Vaccines (Basel). 8 (3), 382.

https://doi.org/10.3390/vaccines8030382

19. Wang L., Shi W., Joyce M.G., Modjarrad K., Zhang Y., Leung K., Lees C.R., Zhou T., Yassine H.M., Kanekiyo M., Yang Z., Chen X., Becker M.M., Freeman M., Vogel L., et al. 2015. Evaluation of candidate vaccine approaches for MERS-CoV. Nat. Commun. 6, 7712. https://doi.org/10.1038/ncomms8712

20. Burton D.R., Hangartner L. 2016. Broadly neutralizing antibodies to HIV and their role in vaccine design. Annu. Rev. Immunol. 34, 635-659.

21. Pancera M., Changela A., Kwong P.D. 2017. How HIV-1 entry mechanism and broadly neutralizing anti- 
bodies guide structure-based vaccine design. Curr. Opin. HIV AIDS. 12, 220-240.

22. Temin H.M. 1993. A proposal for a new approach to a preventive vaccine against human immunodeficiency virus type 1. Proc. Natl. Acad. Sci. U. S. A. 90 (10), 4419-4420.

23. Blish C.A., Dogan O.C., Derby N.R., Nguyen M., Chohan B., Richardson B.A., Overbaugh J. 2008. Human immunodeficiency virus type 1 superinfection occurs despite relatively robust neutralizing antibody responses. Virology. 82 (24), 12094-12103.

24. Vzorov A.N. Uryvaev L.V. 2017. Requirements for the induction of broadly neutralizing antibodies against HIV-1 by vaccination. Mol. Biol. (Moscow). 51 (6), 819-829.

25. van Schooten J., van Gils M.J. 2018. HIV-1 immunogens and strategies to drive antibody responses towards neutralization breadth. Retrovirology. 15, 74 .

https://doi.org/10.1186/s12977-018-0457-7

26. Tong S., Zhu X., Li Y., Shi M., Zhang J., Bourgeois M., Yang H., Chen X., Recuenco S., Gomez J., Chen L., Johnson A., Tao Y., Dreyfus C., Yu W., McBride R., et al. 2013. New world bats harbor diverse influenza a viruses. PLoS Pathog. 9 (10), e 1003657.

27. Carrat F., Flahault A. 2007. Influenza vaccine: The challenge of antigenic drift. Vaccine. 25, 6852-6862.

28. Soema P.C., Kompier R., Amorij J.P., Kersten G.F. 2015. Current and next generation influenza vaccines: Formulation and production strategies. Eur. J. Pharm. Biopharm. 94, 251-263.

29. Wei C.J., Crank M.C., Shiver J., Graham B.S., Mascola J.R., Nabel G.J. 2020. Next-generation influenza vaccines: Opportunities and challenges. Nat. Rev. Drug Discov. 19, 427.

30. Sevajol M., Subissi L., Decroly E., Canard B., Imbert I. 2014. Insights into RNA synthesis, capping, and proofreading mechanisms of SARS-coronavirus. Virus Res. 194, 90-99.

31. Smith E.C., Blanc H., Surdel M.C., Vignuzzi M., Denison M.R. 2013. Coronaviruses lacking exoribonuclease activity are susceptible to lethal mutagenesis: Evidence for proofreading and potential therapeutics. PLoS Pathog. 9, e1003565.

32. Fauver J.R., Petrone M.E., Hodcroft E.B., Shioda K., Ehrlich H.Y., Watts A.G., Vogels C.B.F., Brito A.F., Alpert T., Muyombwe A., Razeq J., Downing R., Cheemarla N.R., Wyllie A.L., Kalinich C.C., et al. 2020. Coast-to-coast spread of SARS-CoV-2 during the early epidemic in the United States. Cell. 181 (5), 990-996.e995.

33. Bazykin G., Stanevich O., Danilenko D. Fadeev A., Komissarova K., Ivanova A., Sergeeva M., Safina K., Nabieva E., Klink G., Garushyants S., Zabutova J., Kholodnaia A., Skorokhod I., Ryabchikova V.V., et al. 2021. Emergence of $\mathrm{Y} 453 \mathrm{~F}$ and $\Delta 69-70 \mathrm{HV}$ mutations in a lymphoma patient with long-term COVID-19. https://virological.org/t/emergence-of-y453f-and-6970hv-mutations-in-a-lymphoma-patient-with-longterm-covid-19/580.

34. Korber B., Fischer W.M., Gnanakaran S., Yoon H., Theiler J., Abfalterer W., Hengartner N., Giorgi E.E., Bhattacharya T., Foley B., Hastie K.M., Parker M. D.,
Partridge D. G., Evans C.M., Freeman T.M., et al. 2020. Tracking changes in SARS-CoV-2 spike: evidence that D614G increases infectivity of the COVID-19 virus. Cell. 182 (4), 812-827, e19.

35. Li Q., Wu J., Nie J., Zhang L., Hao H., Liu S., Zhao C., Zhang Q., Liu H., Nie L., Qin H., Wang M., Lu Q., Li X., Sun Q., Liu J., Zhang L., Li X., Huang W., Wang Y. 2020. The impact of mutations in SARS-CoV-2 spike on viral infectivity and antigenicity. Cell. 182 (5), 1284-1294, e9.

36. Rambaut A., Loman N., Pybus O., Barclay W., Barrett J., Carabelli A., Connor T., Peacock T., Robertson D.L., Volz E., on behalf of COVID-19 Genomics Consortium UK (CoG-UK). 2020. Preliminary genomic characterisation of an emergent SARS-CoV-2 lineage in the UK defined by a novel set of spike mutations. https://virological.org/t/preliminary-genomic-characterisation-of-an-emergent-sars-cov-2-lineage-in-theuk-defined-by-a-novel-set-of-spike-mutations/563.

37. www.cdc.gov/coronavirus/2019-ncov.

38. www.cdc.gov/coronavirus/2019-ncov/cases-updates/ variant-surveillance/variant-info.html.

39. To K.K., Hung I.F., Ip J.D., Chu A.W., Chan W.M., Tam A.R., Fong C.H., Yuan S., Tsoi H.W., Ng A.C., Lee L.L., Wan P., Tso E., To W.K., Tsang D., et al. 2020. COVID-19 re-infection by a phylogenetically distinct SARS-coronavirus-2 strain confirmed by whole genome sequencing. Clin. Infect. Dis. 2020 Aug. 25, ciaa 1275. https://doi.org/10.1093/cid/ciaa1275

40. Rogers T.F., Zhao F., Huang D., Beutler N., Burns A., He W.T., Limbo O., Smith C., Song G., Woehl J., Yang L., Abbott R.K., Callaghan S., Garcia E., Hurtado J., et al. 2020. Rapid isolation of potent SARS-CoV-2 neutralizing antibodies and protection in a small animal model. bioRxiv. 2020.05.11.088674.

https://doi.org/10.1101/2020.05.11.088674

41. Julien J.P., Sok D., Khayat R., Lee J.H., Doores K.J., Walker L.M., Ramos A., Diwanji D.C., Pejchal R., Cupo A., Katpally U., Depetris R.S., Stanfield R.L., McBride R., Marozsan A.J., et al. 2013. Broadly neutralizing antibody PGT121 allosterically modulates CD4 binding via recognition of the HIV-1 gp120 V3 base and multiple surrounding glycans. PLoS Pathog. 9 (5), e1003342.

https://doi.org/10.1371/journal.ppat.1003342

42. Pinto D., Park Y.J., Beltramello M., Walls A.C., Tortorici M.A., Bianchi S., Jaconi S., Culap K., Zatta F., De Marco A., Peter A., Guarino B., Spreafico R., Cameroni E., Case J.B., Chen R.E., et al. 2020. Crossneutralization of SARS-CoV-2 by a human monoclonal SARS-CoV antibody. Nature. 583 (7815), 290-295. https://doi.org/10.1038/s41586-020-2349-y

43. Piccoli L., Park Y.J., Tortorici M.A., Czudnochowski N., Walls A.C., Beltramello M., Silacci-Fregni C., Pinto D., Rosen L.E., Bowen J.E., Acton O.J., Jaconi S., Guarino B., Minola A., Zatta F., et al. 2020. Mapping neutralizing and immunodominant sites on the SARS-CoV-2 spike receptor-binding domain by structure-guided highresolution serology. Cell. 183 (4), 1024-1042, e21. https://doi.org/10.1016/j.cell.2020.09.037

44. Chi X., Yan R., Zhang J., Zhang G., Zhang Y., Hao M., Zhang Z., Fan P., Dong Y., Yang Y., Chen Z., Guo Y., 
Zhang J., Li Y., Song X., et al. 2020. A neutralizing human antibody binds to the $\mathrm{N}$-terminal domain of the spike protein of SARS-CoV-2. Science. 369 (6504), 650-655. https://doi.org/10.1126/science.abc6952

45. Yu J., Tostanoski L.H., Peter L., Mercado N.B., McMahan K., Mahrokhian S.H., Nkolola J.P., Liu J., Li Z., Chandrashekar A., Martinez D.R., Loos C., Atyeo C., Fischinger S., Burke J.S., et al. 2020. DNA vaccine protection against SARS-CoV-2 in rhesus macaques. Science. 369 (6505), 806-811.

https://doi.org/10.1126/science.abc6284

46. McLellan J.S., Chen M., Leung S., Graepel K.W., Du X., Yang Y., Zhou T., Baxa U., Yasuda E., Beaumont T., Kumar A., Modjarrad K., Zheng Z., Zhao M., Xia N., et al. 2013. Structure of RSV fusion glycoprotein trimer bound to a prefusion-specific neutralizing antibody. Science. 340 (6136), 1113-1117.

https://doi.org/10.1126/science.1234914

47. Vzorov A.N., Lea-Fox D., Compans R.W. 1999. Immunogenicity of full length and truncated SIV envelope proteins. Viral. Immunol. 12, 205-215.

48. Tong T., Crooks E.T., Osawa K., Binley J.M. 2012. HIV-1 virus-like particles bearing pure env trimers expose neutralizing epitopes but occlude nonneutralizing epitopes. J. Virol. 86, 3574-3587.

49. Landschulz W.H., Johnson P.F., McKnight S.L. 1988. The leucine zipper: A hypothetical structure common to a new class of DNA binding proteins. Science. $\mathbf{2 4 0}$, 1759-1764.

50. Vzorov A.N., Compans R.W. 2011. Effects of stabilization of the gp41 cytoplasmic domain on fusion activity and infectivity of SIVmac239. AIDS Res. Hum. Retroviruses. 27, 1213-1222.

51. Vzorov A.N., Compans R.W. 2016. VLP vaccines and effects of HIV-1 Env protein modifications on their antigenic properties. Mol. Biol. (Moscow). 50 (3), 353-361.

52. Vzorov A.N., Wang L., Wang B.Z., Compans R.W. 2016. Effects of modification of the HIV-1 Env cytoplasmic tail on immunogenicity of VLP vaccines. Virology. 489, 141-150.

53. Weldon W.C., Wang B.Z., Martin M.P., Koutsonanos D.G., Skountzou I., Compans R.W. 2010. Enhanced immunogenicity of stabilized trimeric soluble influenza hemagglutinin. PLoS One. 5 (9), e 12466. https://doi.org/10.1371/journal.pone.0012466

54. Tang T., Bidon M., Jaimes J.A., Whittaker G.R., Daniel S. 2020. Coronavirus membrane fusion mechanism offers a potential target for antiviral development. Antiviral Res. 178, 104792.

55. Wrapp D., Wang N., Corbett K.S., Goldsmith J.A., Hsieh C.L., Abiona O., Graham B.S., McLellan J.S. 2020. Cryo-EM structure of the 2019-nCoV spike in the prefusion conformation. Science. 367 (6483), 12601263. https://doi.org/10.1126/science.abb2507

56. Rey F.A., Lok S.M. 2018. Common features of enveloped viruses and implications for immunogen design for next-generation vaccines. Cell. 172, 1319-1334. https://doi.org/10.1016/j.cell.2018.02.054

57. Pallesen J., Wang N., Corbett K.S., Wrapp D., Kirchdoerfer R.N., Turner H.L., Cottrell C.A., Becker M.M.,
Wang L., Shi W., Kong W.P., Andres E.L., Kettenbach A.N., Denison M.R., Chappell J.D., et al. 2017. Immunogenicity and structures of a rationally designed prefusion MERS-CoV spike antigen. Proc. Natl. Acad. Sci. U. S. A. 114 (35), E7348-E7357.

https://doi.org/10.1073/pnas.1707304114

58. Xie X., Liu Y., Liu J., Zhang X., Zou J., Fontes-Garfias C.R., Xia H., Swanson K.A., Cutler M., Cooper D., Menachery V.D., Weaver S.C., Dormitzer P.R., Shi P.Y. 2021. Neutralization of SARS-CoV-2 spike 69/70 deletion, E484K and N501Y variants by BNT162b2 vaccine-elicited sera. Nat. Med. 27, 620-621.

https://doi.org/10.1038/s41591-021-01270-4

59. Wibmer C.K., Ayres F., Hermanus T., Madzivhandila M., Kgagudi P., Oosthuysen B., Lambson B.E., de Oliveira T., Vermeulen M., van der Berg K., Rossouw T., Boswell M., Ueckermann V., Meiring S., von Gottberg A., et al. 2021. SARS-CoV-2 501Y.V2 escapes neutralization by South African COVID-19 donor plasma. Nat. Med. 27, 622-625. https://doi.org/10.1038/s41591-021-01285-X

60. WHO. 2020. DRAFT Landscape of COVID-19 Candidate Vaccines - 12 November 2020. https://www.who.int/ publications $/ \mathrm{m} /$ item/draft-landscape-of-covid-19-candidate-vaccines.

61. Logunov D.Y., Dolzhikova I.V., Zubkova O.V., Tukhvatullin A.I., Shcheblyakov D.V., Dzharullaeva A.S., Grousova D.M., Erokhova A.S, Kovyrshina A.V., Botikov A.G., Izhaeva F.M., Popova O., Ozharovskaya T.A., Esmagambetov I.B., Favorskaya I.A., et al. 2020. Safety and immunogenicity of an rAd26 and rAd5 vector-based heterologous prime-boost COVID-19 vaccine in two formulations: Two open, non-randomised phase 1/2 studies from Russia. Lancet. 396 (10255), 887-897. https://doi.org/10.1016/S0140-6736(20)31866-3

62. Corbett K.S., Flynn B., Foulds K.E., Francica J.R., Boyoglu-Barnum S., Werner A.P., Flach B., O'Connell S., Bock K.W., Minai M., Nagata B.M., Andersen H., Martinez D.R., Noe A.T., Douek N., et al. 2020. Evaluation of the mRNA-1273 vaccine against SARS-CoV-2 in nonhuman primates. N. Engl. J. Med. 383 (16), 1544-1555. https://doi.org/10.1056/NEJMoa2024671

63. Mulligan M.J., Lyke K.E., Kitchin N., Absalon J., Gurtman A., Lockhart S., Neuzil K., Raabe V., Bailey R., Swanson K.A., Li P., Koury K., Kalina W., Cooper D., Fontes-Garfias C., et al. 2020. Phase I/II study of COVID-19 RNA vaccine BNT162b1 in adults. Nature. 586 (7830), 589-593. https://doi.org/10.1038/s41586-020-2639-4

64. Folegatti P.M., Ewer K.J., Aley P.K., Angus B., Becker S., Belij-Rammerstorfer S., Bellamy D., Bibi S., Bittaye M., Clutterbuck EA., Dold C., Faust S.N., Finn A., Flaxman A.L., Hallis B., et al. 2020. Safety and immunogenicity of the ChAdOx1 nCoV-19 vaccine against SARSCoV-2: A preliminary report of a phase $1 / 2$, single-blind, randomized controlled trial. Lancet. 396, 467-478.

65. Amanat F., Strohmeier S., Rathnasinghe R., Schotsaert M., Coughlan L., García-Sastre A., Krammer F. 2020. Introduction of two prolines and removal of the polybasic cleavage site leads to optimal efficacy of a recombinant spike based SARS-CoV-2 vaccine in the 
mouse model. bioRxiv. 2020.09.16.300970.

https://doi.org/10.1101/2020.09.16.300970

66. Keech C., Albert G., Cho I., Robertson A., Reed P., Neal S., Plested J.S., Zhu M., Cloney-Clark S., Zhou H., Smith G., Patel N., Frieman M.B., Haupt R.E., Logue J., et al. 2020. Phase $1-2$ trial of a SARS-CoV-2 recombinant spike protein nanoparticle vaccine. N. Engl. J. Med. 383 (24), 2320-2332.

https://doi.org/10.1056/NEJMoa2026920

67. Mercado N.B., Zahn R., Wegmann F., Loos C., Chandrashekar A., Yu J., Liu J., Peter L., McMahan K., Tostanoski L.H., He X., Martinez D.R., Rutten L., Bos R., van Manen D., et al. 2020. Single-shot Ad26 vaccine protects against SARS-CoV-2 in rhesus macaques. $\mathrm{Na}$ ture. 586 (7830), 583-588.

https://doi.org/10.1038/s41586-020-2607-z

68. Laczkó D., Hogan M.J., Toulmin S.A., Hicks P., Lederer K., Gaudette B.T., Castaño D., Amanat F., Muramatsu H., Oguin T.H., 3rd, Ojha A., Zhang L., Mu Z., Parks R., Manzoni T.B., et al. 2020. A single immunization with nucleoside-modified mRNA vaccines elicits strong cellular and humoral immune responses against SARS-CoV-2 in mice. Immunity. 53 (4), 724-732, e7. https://doi.org/10.1016/j.immuni.2020.07.019

69. Zhu F.C., Guan X.H., Li Y.H., Huang J.Y., Jiang T., Hou L.H., Li J.X., Yang B.F., Wang L., Wang W.J., Wu S.P., Wang Z., Wu X.H., Xu J.J., Zhang Z., et al. 2020. Immunogenicity and safety of a recombinant adenovirus type-5-vectored COVID-19 vaccine in healthy adults aged 18 years or older: A randomised, double-blind, placebo-controlled, phase 2 trial. Lancet. 396 (10249), 479-488. https://doi.org/10.1016/S0140-6736(20)31605-6

70. Robert-Guroff M. 2007. Replicating and non-replicating viral vectors for vaccine development. Curr. Opin. Biotechnol. 18, 546-556.

71. Pied N., Wodrich H. 2019. Imaging the adenovirus infection cycle. FEBS Lett. 593 (24), 3419-3448. https://doi.org/10.1002/1873-3468.13690

72. Logunov D.Y., Dolzhikova I.V., Shcheblyakov D.V., Tukhvatulin A.I., Zubkova O.V., Dzharullaeva A.S., Kovyrshina A.V., Lubenets N.L., Grousova D.M.,
Erokhova A.S., Botikov A.G., Izhaeva F.M., Popova O., Ozharovskaya T.A., Esmagambetov I.B., et al. 2021. Safety and efficacy of an rAd26 and rAd5 vector-based heterologous prime-boost COVID-19 vaccine: An interim analysis of a randomised controlled phase 3 trial in Russia. Lancet. 397 (10275), 671-681. https://doi.org/10.1016/S0140-6736(21)00234-8

73. Ledford H. 2021. Why COVID vaccines are so difficult to compare. Nature. 591, 16-17. https://www.nature.com/ articles/d41586-021-00409-0.

74. Iwasaki A., Yang Y. 2020. The potential danger of suboptimal antibody responses in COVID-19. Nat. Rev. Immunol. 20, 339-341.

75. Nechipurenko Y.D., Anashkina A.A., Matveeva O.V. 2020. Change of antigenic determinants of SARS-CoV-2 virus $\mathrm{S}$-protein as a possible cause of antibody-dependent enhancement of virus infection and cytokine storm. Biophysics (Oxf.). 65, 703-709. https://doi.org/10.1134/S0006350920040119

76. Zaichuk T.A., Nechipurenko Yu.D., Adzhubei A.A., Onikienko S.B., Chereshnev V.A., Zainutdinov S.S., Kochneva G.V., Netesov S.V., Matveeva O.V. 2020. The challenges of vaccine development against betacoronaviruses: Antibody dependent enhancement and Sendai virus as a possible vaccine vector. Mol. Biol. (Moscow). 54 (6), 812-826. https://doi.org/10.31857/S0026898420060154

77. Xu J., Zhao S., Teng T., Abdalla A.E., Zhu W., Xie L., Wang Y., Guo X. 2020. Systematic comparison of two animal-to-human transmitted human coronaviruses: SARS-CoV-2 and SARS-CoV. Viruses. 12 (2), 244. https://doi.org/10.3390/v12020244

78. Roncati L., Palmieri B. 2020. What about the original antigenic sin of the humans versus SARS-CoV-2? Med. Hypotheses. 142, 109824. https://doi.org/10.1016/j.mehy.2020.109824

79. Kim J.H., Skountzou I., Compans R., Jacob J. 2009. Original antigenic sin responses to influenza viruses. J. Immunol. 183, 3294-3301.

Translated by E. Martynova 